Technological University Dublin ARROW@TU Dublin

\title{
Synthesis and Characterisation of Tetra-tetrazole Macrocycles
}

\author{
Andrew Bond \\ University of Southern Denmark, Odense \\ Adrienne Fleming \\ Technological University Dublin \\ Fintan Kelleher \\ Technological University Dublin, fintan.kelleher@tudublin.ie
}

See next page for additional authors

Follow this and additional works at: https://arrow.tudublin.ie/ittsciart

Part of the Chemistry Commons

\section{Recommended Citation}

Bond, A., Fleming, A., Kelleher, F., McGinley, J., Prajapati, V., Skovsgaard, S.: Synthesis and Characterisation of Tetra-tetrazole Macrocycles. Tetrahedron, vol. 63 (29), 16 July 2007, p.6835-6842

This Article is brought to you for free and open access by the School of Science and Computing at ARROW@TU Dublin. It has been accepted for inclusion in Articles by an authorized administrator of ARROW@TU Dublin. For more information, please contact

arrow.admin@tudublin.ie, aisling.coyne@tudublin.ie, gerard.connolly@tudublin.ie.

Funder: Irish Government; Danish Natural Sciences

Research Council and the Carlsberg Foundation

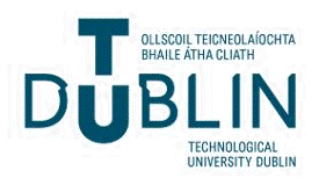




\section{Authors}

Andrew Bond, Adrienne Fleming, Fintan Kelleher, John McGinley, Vipa Prajapati, and Signe Skovsgaard

This article is available at ARROW@TU Dublin: https://arrow.tudublin.ie/ittsciart/14 


\section{Synthesis and characterisation of tetra-tetrazole macrocycles}

Andrew D. Bond, ${ }^{\mathrm{a}}$ Adrienne Fleming, ${ }^{\mathrm{b}}$ Fintan Kelleher, ${ }^{\mathrm{b}}$ John McGinley, ${ }^{\mathrm{c}, *}$ Vipa Prajapati, ${ }^{\mathrm{b}}$ and Signe Skovsgaard. ${ }^{\text {a }}$

${ }^{a}$ Department of Physics and Chemistry, University of Southern Denmark, DK-5230 Odense M, Denmark,

${ }^{b}$ Department of Science and Advanced Smart Materials Research Center, Institute of Technology, Tallaght, Dublin 24, Ireland,

${ }^{c}$ Department of Chemistry, National University of Ireland Maynooth, Maynooth, Co. Kildare, Ireland.

Corresponding Author: Dr. John McGinley

Address : $\quad$ Department of Chemistry,

National University of Ireland Maynooth,

Maynooth,

Co. Kildare,

Ireland.

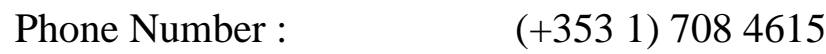

Fax Number : $\quad$ (+353 1) 7083815

e-mail address : $\quad$ john.mcginley@ n $\quad$ nuim.ie 
Synthesis and characterisation of tetra-tetrazole macrocycles

Andrew D. Bond, Adrienne Fleming, Fintan Kelleher, John McGinley, Vipa Prajapati and Signe Skovsgaard.
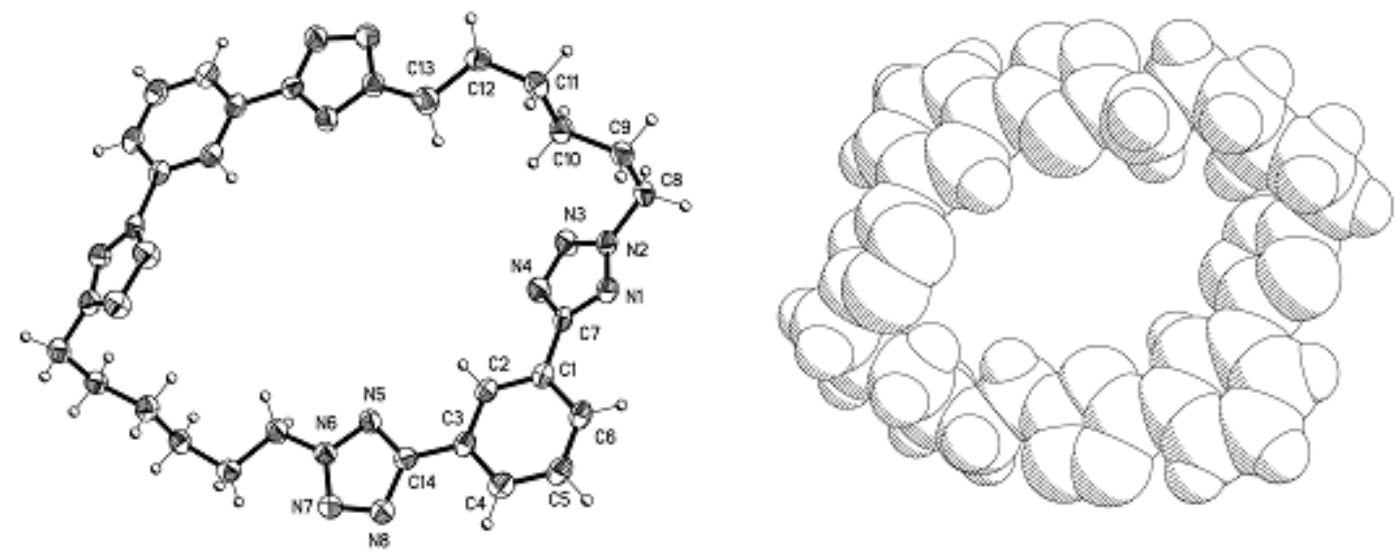


\title{
Synthesis and characterisation of tetra-tetrazole macrocycles
}

Andrew D. Bond, ${ }^{\mathrm{a}}$ Adrienne Fleming, ${ }^{\mathrm{b}}$ Fintan Kelleher, ${ }^{\mathrm{b}}$ John McGinley, ${ }^{\mathrm{c}, *}$ Vipa Prajapati, ${ }^{\mathrm{b}}$ and Signe Skovsgaard. ${ }^{\text {a }}$

${ }^{a}$ Department of Physics and Chemistry, University of Southern Denmark, DK-5230 Odense M, Denmark,

${ }^{b}$ Department of Science and Advanced Smart Materials Research Center, Institute of Technology, Tallaght, Dublin 24, Ireland,

${ }^{c}$ Department of Chemistry, National University of Ireland Maynooth, Maynooth, Co. Kildare, Ireland.

\begin{abstract}
The syntheses of tetra-tetrazole macrocycles, containing two bis-tetrazole units linked by a variety of alkyl chain lengths from four to eight carbons, are described. The crystal structures of three of these derivatives are reported, and the molecular conformation in the solid state is compared to that of one previously reported tetra-tetrazole macrocycle and to other bis- and tris(tetrazole)benzene structures. The macrocycle conformation is influenced by the length of the alkyl chain linker, the relative orientation of the tetrazole rings on the benzene ring, and by intermolecular interactions. In the macrocycles based on 1,2-bis(tetrazole)benzene, the adjacent tetrazole rings on the benzene ring are prevented from becoming co-planar on intramolecular (steric) grounds. In the 1,3- and 1,4bis(tetrazole)benzene derivatives, there is no such impediment, and a co-planar arrangement is observed where intra- and/or intermolecular stacking interactions exist. Deviations from coplanarity are associated with optimisation of intermolecular interactions between the tetrazole rings and adjacent alkyl chains. In the macrocycle based on 1,4-bis(tetrazole)benzene with four-carbon linkers, an intramolecular stacking interaction exists, which precludes the presence of any cavity. In the macrocycle based on 1,3-bis(tetrazole)benzene with six-carbon linkers, a cavity of 10.8 x $9.4 \AA$ is observed for each molecule in the solid state, although the packing of adjacent molecules is such that there are no extended channels running through the crystal.
\end{abstract}

\section{Keywords}

Tetrazole, macrocycles, synthesis, X-ray crystal structure, NMR. 


\section{Introduction}

The growth of tetrazole chemistry over the last twenty-five years has been significant, mainly as a result of the roles played by tetrazoles in coordination chemistry as ligands, in medicinal chemistry as stable surrogates for carboxylic acids and in materials applications, including explosives and photography. ${ }^{1}$ The synthesis of tetrazoles by cycloaddition reactions between azides and nitriles is well documented. ${ }^{2}$ Recently, attention has been directed towards the use of polydentate aromatic nitrogen heterocycles, specifically ligands with five-membered rings, that is azoles. Tetrazoles exhibit a strong networking ability usually acting as mono- or bidentate ligands in most of the reported complexes. ${ }^{3}$ One possible application for these materials is in generating supramolecular arrays which embody additional functional groups capable of metal complexation. This would result in a metallotetrazole framework with possible potential as novel anti-microbial or therapeutic agents. Our interest in tetrazoles concerns their use as precursors for the formation of new functionalised poly-tetrazole macrocycles, which can find application, for example, as sensors or in molecular recognition. We have previously reported some preliminary synthetic steps concerning the addition of pendant short-chain alkyl halides, from dihaloalkanes, to some bis-tetrazoles. ${ }^{4}$ These reactions yield bis-tetrazole derivatives with pendant alkyl halide arms and also bis-tetrazole derivatives with pendant vinyl arms. We have also described the reactions of 1,4bis(tetrazole)benzenes with various long chain $\alpha, \omega$-dibromoalkanes. ${ }^{5}$ Butler and co-workers have synthesised both 1,2- and 1,3-bis(bromoalkyltetrazolyl)benzenes from $N$-unsubstituted tetrazoles and have succeeded in using these bis-(bromoalkyltetrazolyl)-benzenes to generate the tetratetrazole macrocycle. ${ }^{6}$ The latter compound includes a cavity that can be tailored by both the length and flexibility of the alkyl chain and also by the substitution pattern on the benzene ring. ${ }^{7}$ In this paper, we describe the synthesis and characterisation of tetra-tetrazole macrocycles from 1,2-, 1,3and 1,4-benzene derivatives, using short four-carbon, medium six-carbon and long eight-carbon alkyl linkers. The X-ray crystal structures of the 1,2- and 1,4-benzene derivatives with 4-carbon chain linkers are described, as well as the 1,3-benzene derivative containing the 6-carbon linker. Our principal focus is on the variation of the macrocycle cavity shape and dimensions through the series. 


\section{Results and Discussion}

\section{Syntheses}

Butler and co-workers have described the synthesis of tetra-tetrazole macrocycles, based on either 1,2- or 1,3-bis(tetrazol-5-yl)benzenes, with alkyl chains having either six or eight carbon chain linkers. ${ }^{6}$ We have extended this class of compounds by preparing macrocycles with four-carbon chain linkers, and also new macrocycles based on 1,4-bis(tetrazol-5-yl)benzene (Fig. 1). The syntheses were carried out in a manner similar to that described, ${ }^{6}$ by reacting $1, x$-[bis $(2-(y$ bromoalkyl)tetrazol-5-yl]benzene $(x=2,3$ or $4 ; y=4,6$ or 8 ; alkyl = butyl, hexyl or octyl) with 1,n-bis(tetrazol-5-yl)benzene $(n=2,3$ or 4$)$ in dimethylformamide, using $\mathrm{K}_{2} \mathrm{CO}_{3}$ as base. Compounds 2, 3, 5 and $\mathbf{6}$ have been reported previously. ${ }^{6}$<smiles>CC(C)(C)n1nnc(-c2ccccc2-c2nnn(C(C)(C)n3nnc(-c4ccccc4-c4nnn(C(C)(C)C)n4)n3)n2)n1</smiles><smiles>Cn1nnc(-c2ccc(-c3nnn(C)n3)cc2)n1</smiles>

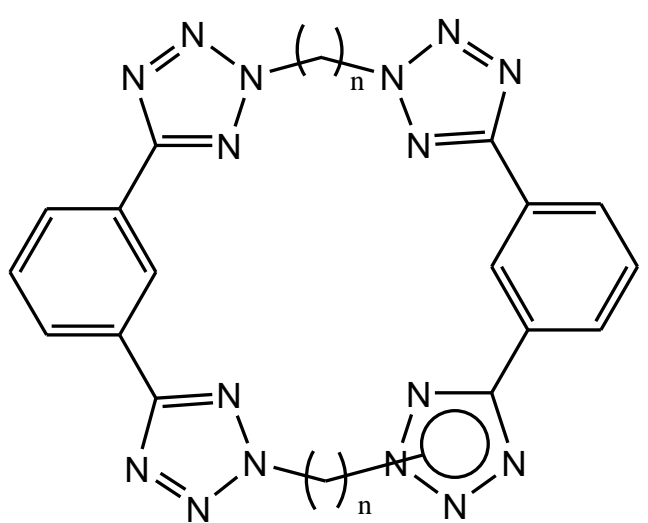

$$
\begin{aligned}
& \mathrm{n}=4 ; \mathbf{4} \\
& \mathrm{n}=6 ; \mathbf{5} \\
& \mathrm{n}=8 ; \mathbf{6}
\end{aligned}
$$

$\mathrm{n}=4 ; 7$

$\mathrm{n}=6 ; 8$

$\mathrm{n}=8 ; 9$

$\mathbf{a}=(2-, 2-, 2-, 2-)$

$\mathbf{b}=(2-, 2-, 2-, 1-)$

Figure 1. Tetra-tetrazole macrocycles 
In several of our reactions, carried out in relatively dilute conditions, two macrocyclic compounds were isolated, one containing all four tetrazole rings substituted at $\mathrm{N}-2$, and the other containing three rings substituted at $\mathrm{N}-2$ and the other one substituted at N-1, as reported previously. ${ }^{6}$ The macrocycles with all four tetrazole rings substituted in the same way will be designated hereafter with the suffix $\mathbf{a}$, while those with one different substitution will be designated with the suffix $\mathbf{b}$.

In all reactions undertaken, on average $40 \%$ of the starting bis-tetrazole compounds were recovered. Extensive column chromatography, using a hexane/ethyl acetate mixture as eluent, was required to separate the product macrocycles from the starting materials and other intractable polymeric material. The isolated yields of the macrocyclic products were in the range $20-25 \%$, which are comparable to those reported by Butler, ${ }^{6}$ and are reasonable for syntheses of this type. One possible reason for the low yields in these reactions is the potential to form polymeric chains between the two bis-tetrazole units, rather than macrocycles. Evidence that some polymeric chains were synthesised came from the fact that intractable material, which could not be dissolved in any solvent we tried, was obtained from all the reactions we attempted. The isomeric $1-N$ - and 2-N-tetrazole derivatives should be readily distinguishable from their respective ${ }^{1} \mathrm{H}$ and ${ }^{13} \mathrm{C}$ NMR spectra, ${ }^{4,5 a, 6,8}$ with the ${ }^{13} \mathrm{C}$ NMR chemical shift of the tetrazole carbon atom appearing at $c a .154 .0$ and $164.0 \mathrm{ppm}$ in N-1 and N-2 substituted tetrazoles, respectively. Macrocycles containing four tetrazole rings all substituted at N-2 gave rise to only a single resonance at $\sim 164.0 \mathrm{ppm}$, while both signals were apparent in the macrocycles containing tetrazole rings substituted at both $\mathrm{N}-1$ and $\mathrm{N}-2$. The high symmetry in the macrocycles containing four tetrazole rings substituted at $\mathrm{N}-2$ also gave a corresponding decrease in the number of signals in the ${ }^{1} \mathrm{H}$ NMR spectra compared to those substituted at both $\mathrm{N}-1$ and $\mathrm{N}-2$.

\section{X-Ray Crystal Stuctures}

We were able to obtain single crystals of the three symmetrical macrocycles $\mathbf{1 a}, \mathbf{5 a}$ and $\mathbf{7 a}$. The crystal structure of $\mathbf{2 a}$ has already been reported. ${ }^{7}$ Attempts to obtain suitable crystals of any of the unsymmetrical macrocycles have so far been unsuccessful. The molecular structures of 1a, 2a, 5a and 7a are shown in Figures 2, 3, 4 and 6 respectively. In each case, the molecule is centrosymmetric and is sited on a crystallographic centre of inversion. For comparison, in particular with regard to the orientations of the tetrazole substituents relative to the benzene ring, 16 further bis- and tris(tetrazole)benzene structures were identified in the Cambridge Structural Database (Version5.27 plus January, May and August updates; 388720 structures in total) ${ }^{9}$ and are listed in Table 1. 
Table 1. 1,2-bis, 1,3-bis, 1,4-bis and 1,3,5-tris(tetrazole)benzene structures identified in the CSD.

\begin{tabular}{llll}
\hline Compound & $\begin{array}{l}\text { CSD } \\
\text { Refcode }\end{array}$ & $\begin{array}{l}\text { Dihedral angles between planes of } \\
\text { tetrazole and benzene rings }\left(^{\circ}\right)\end{array}$ & Reference \\
\hline 1,2-bis(tetrazole)benzenes & & & 8 \\
& DEBSOS & $34.1,34.8$ & $10 \mathrm{a}$ \\
& MARPOK & $55.7,55.7$ & $10 \mathrm{~b}$ \\
& SADCUV & $38.3,58.5$ & $10 \mathrm{~b}$ \\
& SADDAC & $7.7,85.6$ & 4 \\
& SARCEU & $13.3,83.7$ & $10 \mathrm{c}$ \\
& ZUMWOT & $47.9,57.5$ & $10 \mathrm{c}$ \\
& ZUMWUZ & $54.0,56.6 ; 52.5,66.6$ & 8 \\
& & & $10 \mathrm{~d}$ \\
$\mathbf{1 , 3 - b i s ( t e t r a z o l e ) b e n z e n e s}$ & DEBQUW & $13.7,13.7$ & $10 \mathrm{~d}$ \\
& FELZOM & $29.4,42.0$ & 4 \\
& FELZUS & $14.7,24.3 ; 10.1,38.6$ & $10 \mathrm{c}$ \\
& SARCAQ & $6.2,8.8$ & $10 \mathrm{e}$ \\
& ZUMXAG & $8.3,12.1$ & $10 \mathrm{e}$ \\
& & & $10 \mathrm{f}$ \\
$\mathbf{1 , 4 - b i s ( t e t r a z o l e ) b e n z e n e s}$ & ICEGAZ & $6.4,6.4$ & $10 \mathrm{~g}$ \\
\hline
\end{tabular}

The molecular structures of 1a (Fig. 2) and 2a (Fig. 3) are broadly comparable. One of the two unique tetrazole rings (containing N5-N8) lies close to coplanar with the benzene ring to which it is attached (dihedral angle between ring planes $=2.9^{\circ}$ in $\mathbf{1 a}$ and $9.6^{\circ}$ in $\mathbf{2 a}$ ), while the other ring (containing N1-N4) is approximately orthogonal to it (dihedral angle between ring planes $=86.1^{\circ}$ in $\mathbf{1 a}$ and $82.5^{\circ}$ in $\mathbf{2 a}$ ). This arrangement eliminates potential repulsion between adjacent tetrazole

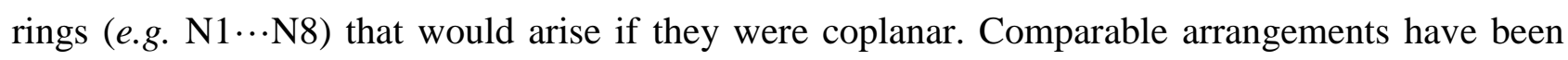
observed in two other 1,2-bis(tetrazole)benzene derivatives, namely SADDAC and SARCEU (Table 1). In all other 1,2-derivatives reported to date (Table 1), both tetrazole rings are twisted from the plane of the benzene ring, with dihedral angles in the range $34.1-66.6^{\circ}$.

In $1 \mathbf{a}$ and $\mathbf{2 a}$, the planes of the benzene and tetrazole rings on opposite sides of the rectangular macrocycle (N5-N8 and its symmetry equivalent) are parallel. The four-carbon chain linkers in 1a adopt an approximately fully-extended conformation, with all four carbon atoms lying in the same plane. In 2a, five of the six carbons of the linker adopt a similar fully-extended conformation, while the sixth (C13) lies gauche with respect to the remainder of the chain (Fig. 3). Macrocycle 1a appears close to a regular rectangle, while $\mathbf{2 a}$ is sheared parallel to the long axis of the alkyl linker. The internal dimensions of the macrocycle (defined as the cross-macrocycle distances between the centroids of the tetrazole rings) are $9.7 \times 5.3 \AA$ in $\mathbf{1 a}$, compared to $11.1 \times 5.6 \AA$ in $\mathbf{2 a}$. Thus, the 
cross-macrocycle distance between the two co-planar tetrazole rings (5.3-5.6 $\AA$ ) changes only slightly with variation of the chain linker. As noted by Butler et al., ${ }^{7}$ space-filling representations of 1a and 2a (Figs 2 and 3) show that the central "cavity" of the macrocycle is largely illusory, at least for the conformation observed in the solid state.
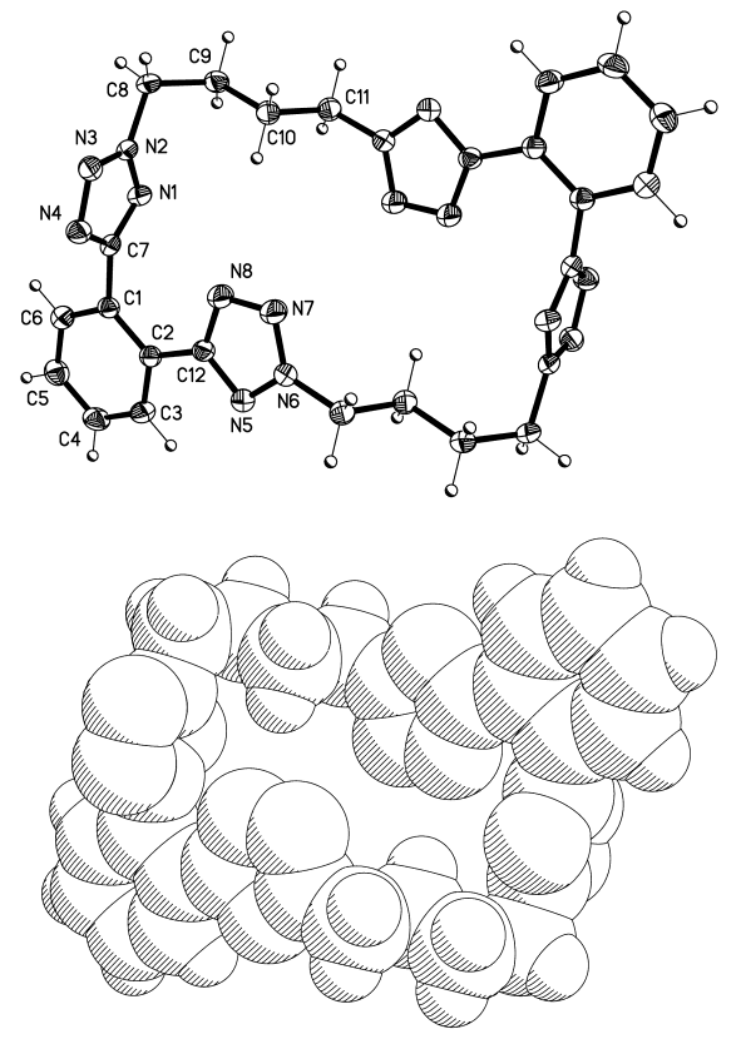

Figure 2. Molecular structure of 1a showing displacement ellipsoids at the $50 \%$ probability level for non-H atoms (top), and a space-filling representation (bottom). 

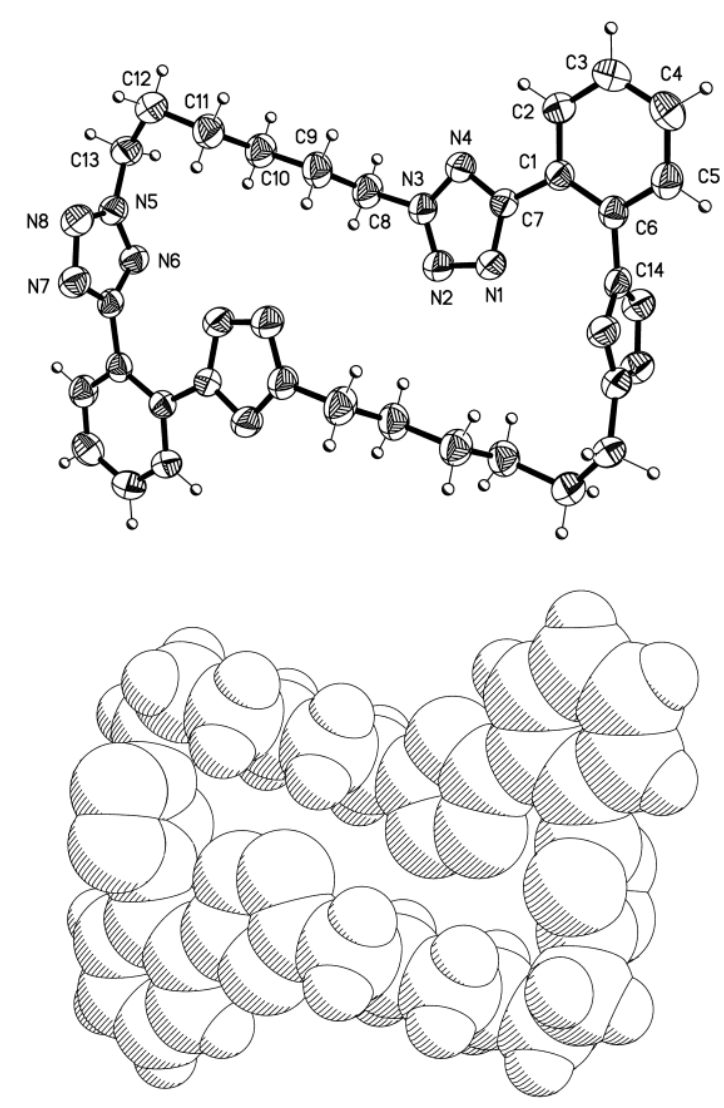

Figure 3. Molecular structure of $\mathbf{2 a}$ showing displacement ellipsoids at the 50\% probability level for non-H atoms (top), and a space-filling representation (bottom). ${ }^{7}$

In the structure of 5a (Fig. 4), both unique tetrazole rings remain close to coplanar with the benzene ring to which they are attached. The dihedral angle between the tetrazole and benzene ring is 25.2 and $5.6^{\circ}$ for N1-N4 and N5-N8, respectively. Comparison with other 1,3-bis(tetrazole)benzene structures (Table 1) shows that approximate co-planarity (considered to encompass the range 6.2 $14.7^{\circ}$ ) is common, and the structures of DEBQUW, SARCAQ and ZUMXAG show explicitly that there is no intramolecular impediment to approximate co-planarity of both rings. The moderate deviation from co-planarity for $\mathrm{N} 1-\mathrm{N} 4$ in 5a seems attributable, therefore, to optimisation of intermolecular contacts (see below) rather than any intramolecular feature. Similar to $\mathbf{2 a}$, the sixcarbon chain linker in $\mathbf{5 a}$ exhibits an essentially fully-extended conformation for five of its six carbon atoms, while the sixth $(\mathrm{C} 13)$ lies approximately gauche with respect to the remainder of the chain. The macrocycle geometry, in this case, is close to a regular square, with cross-macrocycle dimensions $10.8 \times 9.4 \AA$. A space-filling representation of the structure (Fig. 4) shows that a genuine cavity is retained in the solid state. 

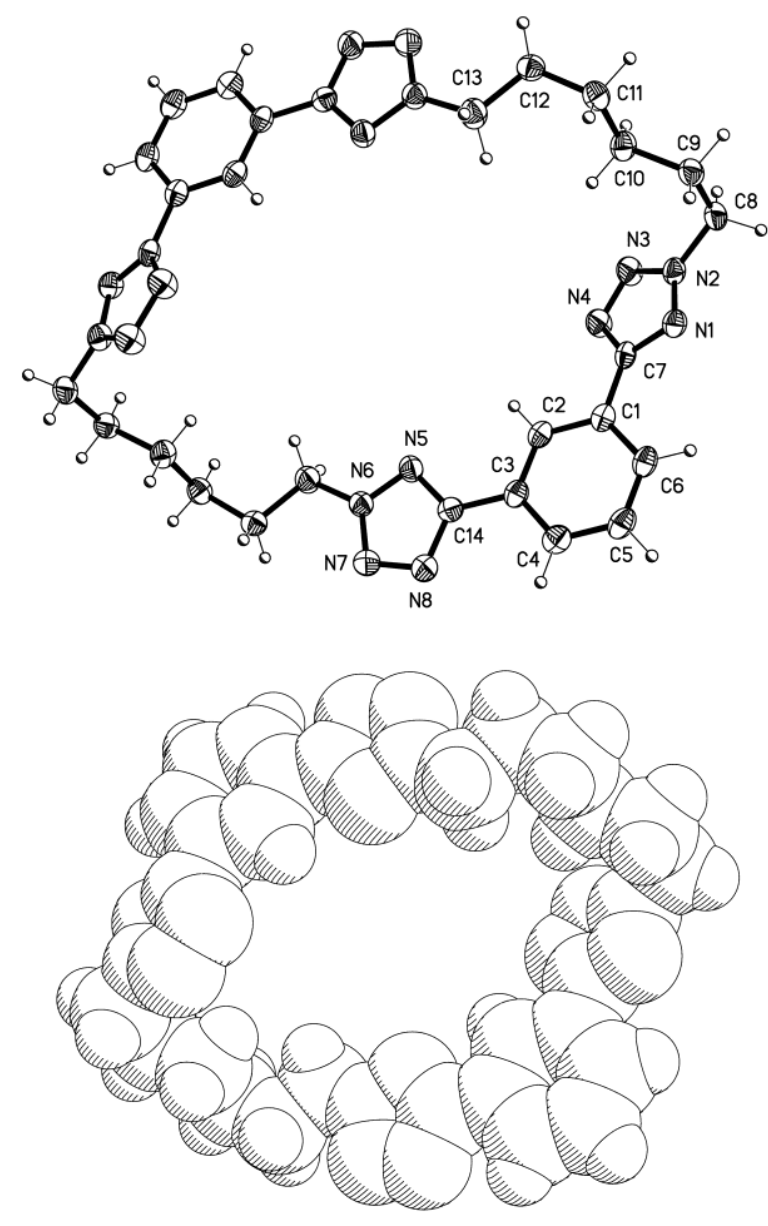

Figure 4. Molecular structure of 5a showing displacement ellipsoids at the $50 \%$ probability level for non-H atoms (top), and a space-filling representation (bottom).

Adjacent macrocycles in $\mathbf{5 a}$ are arranged so that one benzene-tetrazole unit lies over the cavity of the adjacent macrocycle (Fig. 5a), forming a local stacking arrangement similar to that seen within 7a (see below). On account of this packing arrangement, there are no extended channels running through the crystal. The interplanar separation between stacked benzene rings in this region is 3.68 $\AA$ and the benzene centroid-to-centroid distance is $5.16 \AA$. A shorter contact of $4.05 \AA$ exists between the centroid of the benzene ring and the centroid of one adjacent tetrazole ring (N5-N8). Involvement of the N5-N8 ring in this stacking interaction is consistent with its co-planarity with the benzene ring. In projection (Fig. 5b), the stacked macrocycles closely resemble 7a (Fig. 6). They are arranged in a herring-bone manner, which brings the tetrazole ring N1-N4 into the vicinity of an adjacent alkyl chain. The $25.2^{\circ}$ twist of the tetrazole ring with respect to the benzene ring brings its mean plane parallel to that of the fully-extended section of the alkyl chain (C8-C12). Thus, the moderate twist of ring N1-N4 can be attributed clearly to optimisation of this intermolecular interaction. 
(a)

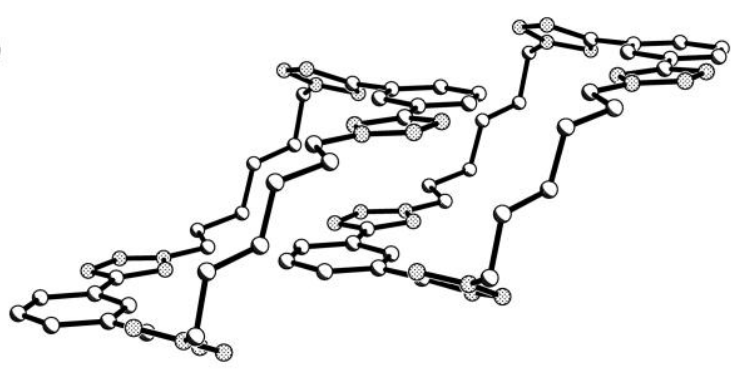

(b)

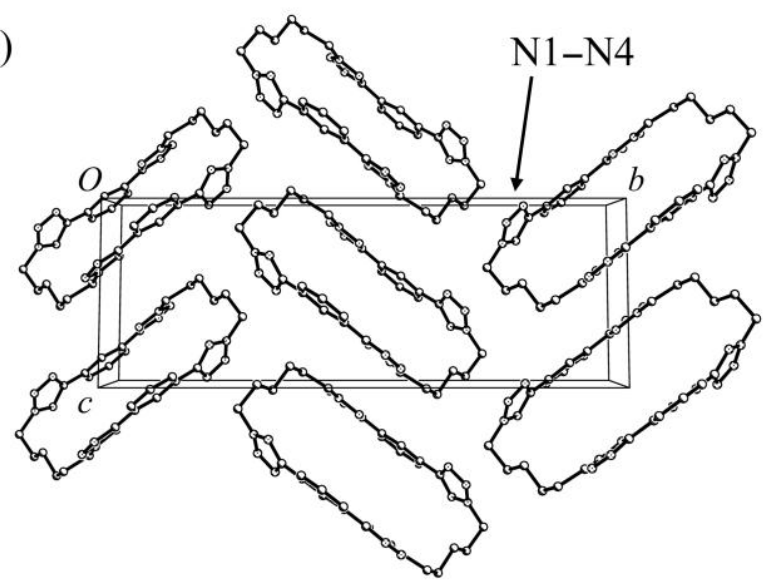

Figure 5. (a) Stacking interaction between adjacent macrocycles in 5a. (b) Projection of 5a approximately along the $a$ axis, showing the herring-bone arrangement, which brings tetrazole ring N1-N4 into close contact with an alkyl chain of the adjacent macrocycle.

In 7a (Fig. 6), the four-carbon chain linkers permit an intramolecular stacking interaction, similar to that observed in macrocyclic systems such as bis(1,4-phenylene)crown ethers with ether chain linkers of appropriate length. ${ }^{11}$ The interplanar separation is $3.44 \AA$ and the benzene centroid-tocentroid distance is $3.91 \AA$. Clearly, this precludes the existence of any cavity within the macrocycle, and this interaction is likely to persist in solution. The tetrazole rings lie approximately co-planar with the benzene rings to which they are attached, forming dihedral angles 10.8 and $4.8^{\circ}$ for the N1-N4 and N5-N8 rings, respectively, consistent with their participation in the stacking interaction. The approximately co-planar arrangement is most common in all previously examined 1,4-bis(tetrazole)benzene structures (Table 1). Face-to-face stacking of 1,4-bis(tetrazole)benzene units is also observed between macrocycles for $\mathbf{7 a}$ in the solid state. The shortest additional contacts to the tetrazole ring are in-plane $\mathrm{C}-\mathrm{H} \cdots \mathrm{N}$ interactions. 

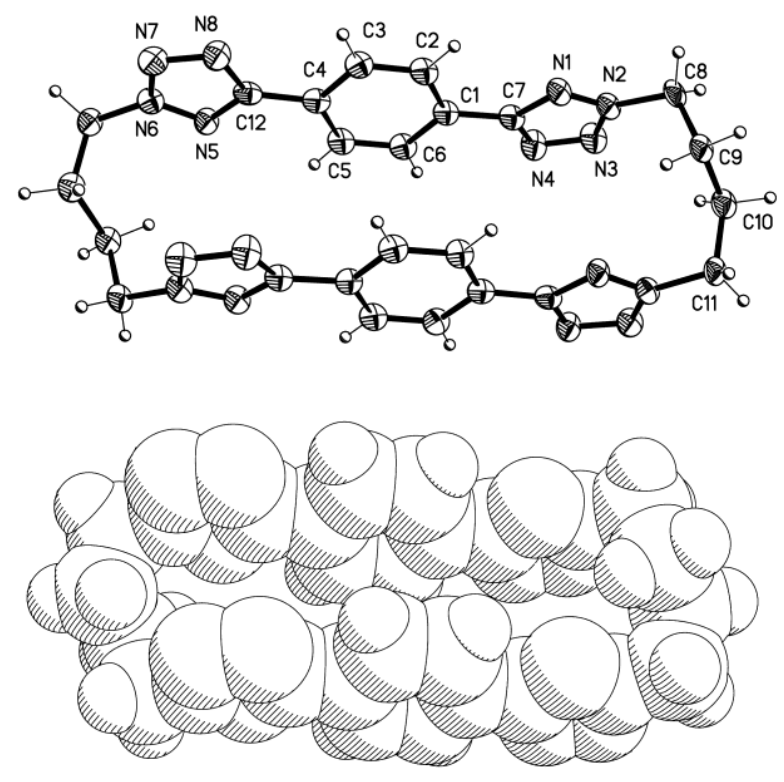

Figure 6. Molecular structure of 7a showing displacement ellipsoids at the 50\% probability level for non-H atoms (top), and a space-filling representation (bottom).

\section{Conclusions}

In the solid state, the conformation of the macrocycle is influenced by the orientation of the tetrazole rings on the benzene ring, by the length of the alkyl-chain linkers and by intermolecular interactions. In the macrocycles based on 1,2-bis(tetrazole)benzene, the adjacent tetrazole substituents on the benzene ring are prevented from becoming co-planar on steric grounds. In both 1a and $\mathbf{2 a}$, the resulting conformation is such that no genuine cavity is retained. In the macrocycles based on 1,3- and 1,4-bis(tetrazole)benzene, there is no intramolecular impediment to co-planarity of the tetrazole rings with the benzene ring, and co-planarity is observed where stacking interactions are present. In 5a, these stacking interactions are intermolecular, while in $\mathbf{7 a}$ they are intramolecular. In the former case, one tetrazole ring is twisted slightly out of the plane of the benzene ring to which it is bound, apparently to optimise intermolecular interactions with an adjacent alkyl chain. In 7a, the intramolecular stacking interaction precludes the existence of any cavity, and this interaction is likely to persist in solution. In 5a, however, a genuine cavity of dimensions $10.8 \times 9.4 \AA$ is retained in the solid state, and appears feasible in solution. Currently, metal complexation reactions with this macrocycle are currently being investigated. We are interested in looking at both first row transition metal ions as well as some smaller alkali and alkaline earth metals, as metal ions from these groups using tetrazoles as ligands in coordination chemistry are described in the literature. ${ }^{12}$ 


\section{Experimental}

${ }^{1} \mathrm{H}$ and ${ }^{13} \mathrm{C}$ NMR ( $\delta$ ppm; $J \mathrm{~Hz}$ ) spectra were recorded on a JEOL JNM-LA300 FT-NMR spectrometer using saturated $\mathrm{CDCl}_{3}$ solutions with $\mathrm{Me}_{4} \mathrm{Si}$ reference, unless indicated otherwise, with resolutions of $0.18 \mathrm{~Hz}$ and $0.01 \mathrm{ppm}$, respectively. Infrared spectra $\left(\mathrm{cm}^{-1}\right)$ were recorded as $\mathrm{KBr}$ discs or liquid films between $\mathrm{KBr}$ plates using a Nicolet Impact 410 FT-IR. Melting point analysis was carried out using a Stewart Scientific SMP 1 melting point apparatus and are uncorrected. Mass spectra were carried out in the Mass Spectroscopy unit in the Centre for Synthesis and Chemical Biology, University College, Dublin. Microanalysis was carried out at the Microanalytical Laboratory of University College, Dublin. Standard Schlenk techniques were used throughout. Starting materials were commercially obtained and used without further purification. The synthesis of compounds $\mathbf{2 a},{ }^{6 \mathrm{~b}} \mathbf{3 a},{ }^{6 \mathrm{~b}} \mathbf{5} \mathbf{a}^{6 \mathrm{c}}$ and $\mathbf{6} \mathbf{a}^{6 \mathrm{c}}$ have been described in the literature previously.

\section{General Syntheses of tetra-tetrazolophanes}

A mixture of 1,n-bis(tetrazol-5-yl)benzene $(1.1 \mathrm{mmol})$ and potassium carbonate $(1.5 \mathrm{~g}, 11 \mathrm{mmol})$ in dimethylformamide $(60 \mathrm{ml})$ was stirred for one hour at $75{ }^{\circ} \mathrm{C}$ under an nitrogen atmosphere, and treated with 1,n-bis(2-(n-bromoalkyl)tetrazol-5-yl)]benzene $(1.1 \mathrm{mmol})$ and stirred at $75{ }^{\circ} \mathrm{C}$ for 24 h. Insoluble salts, filtered from the cooled mixture, were washed with ethyl acetate and the combined washings and mother-liquor were evaporated under reduced pressure. The oily residue was chromatographed on silica gel using ethyl acetate : hexane $(50: 50)$ as eluent to give the cyclophane. All compounds were then recrystallised from chloroform.

Di-orthobenzenotetra(5', 2'-tetrazolo)[5'-(2)-2'-(4)]-cyclophane (2-N, 2-N', 2-N", 2-N"') (1a).

White solid. Analysis: Found: C, 54.02; H, 4.81; N, 41.42. Calc. For $\mathrm{C}_{24} \mathrm{H}_{24} \mathrm{~N}_{16}$ : C, 53.72; H, 4.51; N, 41.77; Yield: $33 \mathrm{mg}, 12.3 \%, 0.06$ mmol; $\mathrm{R}_{\mathrm{f}} 0.52$ (50 : 50 hexane : ethyl acetate); M.p. 224-228 ${ }^{\circ} \mathrm{C} ; v_{\max }(\mathrm{KBr}) 3150,3090,2955,2828,1724,1500,1499,1467,1440,1391,1359,1285,1178$, 1038, 787, 775, 730, $668 \mathrm{~cm}^{-1} ; \delta_{\mathrm{H}}: 1.89\left(\mathrm{~m}, 8 \mathrm{H}, \mathrm{CH}_{2}\right), 4.64\left(\mathrm{t}, 8 \mathrm{H}, J=13.6 \mathrm{~Hz}, \mathrm{NCH}_{2}\right), 7.81(\mathrm{~m}, 4$ $\mathrm{H}, \mathrm{Ar}-\mathrm{H}), 7.95$ (m, $4 \mathrm{H}, \mathrm{Ar}-\mathrm{H}) ; \delta_{\mathrm{C}}: 29.1,52.0$ (tetrazole N2-CH ), 127.6, 130.3, 131.1, 164.5 (2,5tetrazole); HRMS (EI) Calc. 537.2448, Found 537.2422.

Di-orthobenzenotetra(5', 2'-tetrazolo)[5'-(2)-2'-(4)]-cyclophane (1-N, 2-N', 2-N", 2-N"') (1b). 
White waxy solid. Analysis: Found: C, 53.57; H, 4.84; N, 41.99. Calc. For $\mathrm{C}_{24} \mathrm{H}_{24} \mathrm{~N}_{16}$ : C, 53.72; $\mathrm{H}$, 4.51; N, 41.77; Yield: $22 \mathrm{mg}, 8.2 \%, 0.04 \mathrm{mmol} ; \mathrm{R}_{\mathrm{f}} 0.42$ (50 : 50 hexane : ethyl acetate); $v_{\max }(\mathrm{KBr})$ 3440, 2942, 2870, 1625, 1520, 1435, 1389, 1360, 1199, 1087, 1050, 910, 812, 787, 745, $692 \mathrm{~cm}^{-1}$; $\delta_{\mathrm{H}}: 1.91\left(\mathrm{~m}, 6 \mathrm{H}, \mathrm{CH}_{2}\right), 2.13\left(\mathrm{~m}, 2 \mathrm{H}, \mathrm{CH}_{2}\right), 4.64\left(\mathrm{t}, 2 \mathrm{H}, J=14.6 \mathrm{~Hz}, \mathrm{~N}^{1} \mathrm{CH}_{2}\right), 4.77(\mathrm{t}, 6 \mathrm{H}, J=$ 13.6 Hz, N $\left.\mathrm{CH}_{2}\right), 7.48$ (d, $\left.1 \mathrm{H}, J=6.6 \mathrm{~Hz}, \mathrm{Ar}-\mathrm{H}\right), 7.66$ (t, $\left.1 \mathrm{H}, J=13.0 \mathrm{~Hz}, \mathrm{Ar}-\mathrm{H}\right), 7.76$ (d, $3 \mathrm{H}, J=$ $6.6 \mathrm{~Hz}, \mathrm{Ar}-\mathrm{H}$ ), 8.37 (t, $3 \mathrm{H}, J=13.0 \mathrm{~Hz}, \mathrm{Ar}-\mathrm{H}$ ); $\delta_{\mathrm{C}}: 29.0,29.1,46.6$ (tetrazole N1-CH 2 ), 52.6 (tetrazole N2- $\mathrm{CH}_{2}$ ), 52.8 (tetrazole N2- $\mathrm{CH}_{2}$ ), 52.9 (tetrazole $\mathrm{N} 2-\mathrm{CH}_{2}$ ), 122.9, 127.2, 127.3, 127.5, 129.4, 130.3, 130.6, 130.8, 131.1, 131.5, 154.1 (1,5-tetrazole), 162.7 (2,5-tetrazole), 163.1 (2,5tetrazole), 164.1 (2,5-tetrazole); HRMS (EI) Calc. 537.2448, Found 537.2437.

Di-orthobenzenotetra(5', 2'-tetrazolo)[5'-(2)-2'-(6)]-cyclophane (2-N, 2-N', 2-N", 2-N"') (2a). ${ }^{6 b}$ White solid. Analysis: M.p. 178-180 ${ }^{\circ} \mathrm{C} ; \mathrm{R}_{\mathrm{f}} 0.50$ (50: 50 hexane : ethyl acetate); $\delta_{\mathrm{H}}: 1.37$ (m, $8 \mathrm{H}$, $\left.\mathrm{CH}_{2}\right), 2.00\left(\mathrm{~m}, 8 \mathrm{H}, \mathrm{CH}_{2}\right), 4.59$ (t, $\left.8 \mathrm{H}, J=13.5 \mathrm{~Hz}, \mathrm{NCH}_{2}\right), 7.59$ (m, $\left.4 \mathrm{H}, \mathrm{Ar}-\mathrm{H}\right), 7.91$ (m, $4 \mathrm{H}, \mathrm{Ar}-$ $\mathrm{H})$.

Di-orthobenzenotetra(5', 2'-tetrazolo)[5'-(2)-2'-(6)]-cyclophane (1-N, 2-N', 2-N", 2-N"') (2b).

White solid. Analysis: Found: C, 56.96; H, 5.18; N, 37.86. Calc. For $\mathrm{C}_{28} \mathrm{H}_{32} \mathrm{~N}_{16}$ : C, 56.74; H, 5.44; N, 37.81; Yield: $49 \mathrm{mg}, 18.2 \%, 0.08 \mathrm{mmol} ; \mathrm{R}_{\mathrm{f}} 0.40$ (50 : 50 hexane : ethyl acetate); M.p. 128-130 ${ }^{\circ} \mathrm{C} ; v_{\max }(\mathrm{KBr}) 3435,2925,2858,1629,1555,1450,1359,1275,1198,1049,1099,855,746,729$, $671 \mathrm{~cm}^{-1} ; \delta_{\mathrm{H}}: 1.30\left(\mathrm{~m}, 14 \mathrm{H}, \mathrm{CH}_{2}\right), 1.75\left(\mathrm{~m}, 2 \mathrm{H}, \mathrm{CH}_{2}\right), 4.03\left(\mathrm{t}, 2 \mathrm{H}, J=14.2 \mathrm{~Hz}, \mathrm{~N}^{1} \mathrm{CH}_{2}\right), 4.63(\mathrm{t}, 6$ $\left.\mathrm{H}, J=13.5 \mathrm{~Hz}, \mathrm{~N}^{1} \mathrm{CH}_{2}\right), 7.48(\mathrm{~d}, 1 \mathrm{H}, J=6.6 \mathrm{~Hz}, \mathrm{Ar}-\mathrm{H}), 7.66(\mathrm{t}, 1 \mathrm{H}, J=13.0 \mathrm{~Hz}, \mathrm{Ar}-\mathrm{H}), 7.73(\mathrm{~d}, 3$ $\mathrm{H}, J=6.6 \mathrm{~Hz}, \mathrm{Ar}-\mathrm{H}), 8.30$ (t, $3 \mathrm{H}, J=13.0 \mathrm{~Hz}, \mathrm{Ar}-\mathrm{H}) ; \delta_{\mathrm{C}}: 25.1$, 25.3, 25.4, 25.5, 28.2, 28.6, 28.7, 28.8, 47.1 (tetrazole N1- $\mathrm{CH}_{2}$ ), 52.5 (tetrazole $\mathrm{N} 2-\mathrm{CH}_{2}$ ), 52.7 (tetrazole N2- $\mathrm{CH}_{2}$ ), 53.4 (tetrazole $\left.\mathrm{N} 2-\mathrm{CH}_{2}\right), 122.8,127.2,127.5,129.5,130.0,130.2,130.3,130.8,131.5,153.8$ (1,5-tetrazole), 162.8 (2,5-tetrazole), 164.1 (2,5-tetrazole), 164.1 (2,5-tetrazole); HRMS (EI) Calc. 593.3074, Found 593.3100 .

Di-orthobenzenotetra(5', 2'-tetrazolo)[5'-(2)-2'-(8)]-cyclophane (2-N, 2-N', 2-N", 2-N"') (3a). ${ }^{6 b}$

White solid. Analysis: M.p. $148-150{ }^{\circ} \mathrm{C}$ (lit. 147-148 ${ }^{\circ} \mathrm{C}$ ); $\mathrm{R}_{\mathrm{f}} 0.53$ (50: 50 hexane : ethyl acetate); $\delta_{\mathrm{H}}: 1.35\left(\mathrm{~m}, 12 \mathrm{H}, \mathrm{CH}_{2}\right), 1.96\left(\mathrm{~m}, 12 \mathrm{H}, \mathrm{CH}_{2}\right), 4.57$ (t, $\left.8 \mathrm{H}, J=13.9 \mathrm{~Hz}, \mathrm{NCH}_{2}\right), 7.60$ (m, $4 \mathrm{H}, \mathrm{Ar}-$ $\mathrm{H}), 7.91$ (m, $4 \mathrm{H}, \mathrm{Ar}-\mathrm{H})$.

Di-orthobenzenotetra(5', 2'-tetrazolo)[5'-(2)-2'-(8)]-cyclophane (1-N, 2-N', 2-N", 2-N'") (3b). 
White solid. Analysis: Found: C, 59.60; H, 6.41; N, 34.40. Calc. For $\mathrm{C}_{32} \mathrm{H}_{40} \mathrm{~N}_{16}$ : C, 59.24; H, 6.21; N, 34.54; Yield: 55 mg, $20.4 \%, 0.08$ mmol; $R_{\mathrm{f}} 0.40$ (50 : 50 hexane : ethyl acetate); M.p. 146-148 ${ }^{\circ} \mathrm{C}$; $v_{\max }(\mathrm{KBr}) 3435,2940,2868,1625,1522,1430,1390,1360,1199,1087,1048,910,810,787$, 745, $690 \mathrm{~cm}^{-1}$; $\delta_{\mathrm{H}}: 1.34\left(\mathrm{~m}, 22 \mathrm{H}, \mathrm{CH}_{2}\right), 1.72\left(\mathrm{~m}, 2 \mathrm{H}, \mathrm{CH}_{2}\right), 4.05\left(\mathrm{t}, 2 \mathrm{H}, J=14.6 \mathrm{~Hz}, \mathrm{~N}^{1} \mathrm{CH}_{2}\right)$, $4.55\left(\mathrm{t}, 6 \mathrm{H}, J=13.6 \mathrm{~Hz}, \mathrm{~N}^{2} \mathrm{CH}_{2}\right), 7.48(\mathrm{~d}, 1 \mathrm{H}, J=6.6 \mathrm{~Hz}, \mathrm{Ar}-\mathrm{H}), 7.66$ (t, $\left.1 \mathrm{H}, J=13.0 \mathrm{~Hz}, \mathrm{Ar}-\mathrm{H}\right)$, $7.74(\mathrm{~d}, 3 \mathrm{H}, J=6.6 \mathrm{~Hz}, \mathrm{Ar}-\mathrm{H}), 8.35$ (t, $3 \mathrm{H}, J=13.0 \mathrm{~Hz}, \mathrm{Ar}-\mathrm{H})$; $\delta_{\mathrm{C}}: 25.8,25.9,26.1,26.1,28.4$, 28.4, 28.5, 28.6, 28.6, 28.8, 29.1, 29.2, 47.3 (tetrazole N1- $\mathrm{CH}_{2}$ ), 52.8 (tetrazole N2- $\mathrm{CH}_{2}$ ), 52.8 (tetrazole N2- $\mathrm{CH}_{2}$ ), 53.1 (tetrazole $\mathrm{N} 2-\mathrm{CH}_{2}$ ), 123.1, 127.4, 127.7, 129.5, 130.1, 130.4, 130.4, 130.5, 130.8, 131.6, 153.9 (1,5-tetrazole), 162.9 (2,5-tetrazole), 164.1 (2,5-tetrazole), 164.3 (2,5tetrazole); HRMS (EI) Calc. 649.3700, Found 649.3679.

Di-metabenzenotetra(5', 2'-tetrazolo)[5'-(2)-2'-(4)]-cyclophane (2-N, 2-N', 2-N", 2-N"') (4a).

White solid. Analysis: Found: C, 53.39; H, 4.43; N, 41.85. Calc. For $\mathrm{C}_{24} \mathrm{H}_{24} \mathrm{~N}_{16}$ : C, 53.72; H, 4.51; N, 41.77; Yield: 24 mg, $9.0 \%, 0.04$ mmol; $\mathrm{R}_{\mathrm{f}} 0.50$ (50 : 50 hexane : ethyl acetate); M.p. 284-286 ${ }^{\circ} \mathrm{C}$; $v_{\max }(\mathrm{KBr}) 3430,2952,2830,1724,1520,1468,1442,1390,1359,1285,1179,1038,787,774$, 730, $667 \mathrm{~cm}^{-1} ; \delta_{\mathrm{H}}: 1.89\left(\mathrm{~m}, 8 \mathrm{H}, \mathrm{CH}_{2}\right), 4.65\left(\mathrm{t}, 8 \mathrm{H}, J=13.5 \mathrm{~Hz}, \mathrm{NCH}_{2}\right), 7.63(\mathrm{t}, 2 \mathrm{H}, J=15.5 \mathrm{~Hz}$, Ar-H), 8.27 (d, $4 \mathrm{H}, J=6.6 \mathrm{~Hz}, \mathrm{Ar}-\mathrm{H}), 8.82$ (s, $2 \mathrm{H}, \mathrm{Ar}-\mathrm{H}) ; \delta_{\mathrm{C}}: 29.1,52.0$ (tetrazole N2-CH 2 ), 125.2, 128.2, 128.5, 129.6, 164.6 (2,5-tetrazole); HRMS (EI) Calc. 537.2448, Found 537.2452.

Di-metabenzenotetra(5', 2'-tetrazolo)[5'-(2)-2'-(6)]-cyclophane (2-N, 2-N', 2-N", 2-N"') (5a). ${ }^{6 \mathrm{c}}$ White solid. Analysis: M.p. $150-152{ }^{\circ} \mathrm{C}$ (lit. $\left.150-152{ }^{\circ} \mathrm{C}\right) ; \mathrm{R}_{\mathrm{f}} 0.52$ (50: 50 hexane : ethyl acetate); $\delta_{\mathrm{H}}: 1.37\left(\mathrm{~m}, 8 \mathrm{H}, \mathrm{CH}_{2}\right), 2.04\left(\mathrm{~m}, 8 \mathrm{H}, \mathrm{CH}_{2}\right), 4.67\left(\mathrm{t}, 8 \mathrm{H}, J=13.5 \mathrm{~Hz}, \mathrm{NCH}_{2}\right), 7.63(\mathrm{t}, 2 \mathrm{H}, J=6.5$ $\mathrm{Hz}, \mathrm{Ar}-\mathrm{H}), 8.27$ (d, $4 \mathrm{H}, J=6.5 \mathrm{~Hz}, \mathrm{Ar}-\mathrm{H}), 8.82$ (s, $2 \mathrm{H}, \mathrm{Ar}-\mathrm{H})$.

Di-metabenzenotetra(5', 2'-tetrazolo)[5'-(2)-2'-(6)]-cyclophane (1-N, 2-N', 2-N", 2-N"') (5b).

White solid. Analysis: Found: C, 57.05; H, 5.20; N, 37.53. Calc. For $\mathrm{C}_{28} \mathrm{H}_{32} \mathrm{~N}_{16}$ : C, 56.74; H, 5.44; N, 37.81; Yield: $26 \mathrm{mg}, 9.8 \%, 0.04 \mathrm{mmol} ; \mathrm{R}_{\mathrm{f}} 0.40$ (50: 50 hexane : ethyl acetate); M.p. 148-150 ${ }^{\circ} \mathrm{C}$; $v_{\max }(\mathrm{KBr}) 3440,2925,2850,1630,1560,1451,1360,1274,1196,1046,1005,854,746,730$, $669 \mathrm{~cm}^{-1} ; \delta_{\mathrm{H}}: 1.26\left(\mathrm{~m}, 8 \mathrm{H}, \mathrm{CH}_{2}\right), 1.75\left(\mathrm{~m}, 2 \mathrm{H}, \mathrm{CH}_{2}\right), 4.48\left(\mathrm{t}, 2 \mathrm{H}, J=14.4 \mathrm{~Hz}, \mathrm{~N}^{1} \mathrm{CH}_{2}\right), 4.67(\mathrm{t}, 6$ $\left.\mathrm{H}, J=13.5 \mathrm{~Hz}, \mathrm{~N}^{2} \mathrm{CH}_{2}\right), 7.63$ (t, $\left.2 \mathrm{H}, J=6.6 \mathrm{~Hz}, \mathrm{Ar}-\mathrm{H}\right), 7.81$ (d, $\left.2 \mathrm{H}, J=6.6 \mathrm{~Hz}, \mathrm{Ar}-\mathrm{H}\right), 8.27$ (d, 2 $\mathrm{H}, J=6.6 \mathrm{~Hz}, \mathrm{Ar}-\mathrm{H}), 8.83(\mathrm{~s}, 2 \mathrm{H}, \mathrm{Ar}-\mathrm{H}) ; \delta_{\mathrm{C}}: 26.1,26.2,26.3,26.4,29.5,29.5,29.6,29.7,49.0$ (tetrazole N1- $\mathrm{CH}_{2}$ ), 53.8 (tetrazole N2- $\mathrm{CH}_{2}$ ), 53.9 (tetrazole N2- $\mathrm{CH}_{2}$ ), 54.0 (tetrazole N2- $\mathrm{CH}_{2}$ ), 124.7, 125.3, 127.0, 128.6, 128.9, 129.2, 129.8, 129.9, 130.1, 130.5, 130.9, 154.1 (1,5-tetrazole), 
162.8 (2,5-tetrazole), 164.3 (2,5-tetrazole), 165.0 (2,5-tetrazole); HRMS (EI) Calc. 593.3074, Found 593.3065.

Di-metabenzenotetra(5', 2'-tetrazolo)[5'-(2)-2'-(8)]-cyclophane (2-N, 2-N', 2-N", 2-N"') (6a). ${ }^{6 c}$

White solid. Analysis: M.p. $144-148^{\circ} \mathrm{C}$ (lit. $\left.144-146{ }^{\circ} \mathrm{C}\right) ; \mathrm{R}_{\mathrm{f}} 0.53$ (50: 50 hexane : ethyl acetate); $\delta_{\mathrm{H}}: 1.35\left(\mathrm{~m}, 12 \mathrm{H}, \mathrm{CH}_{2}\right), 1.96\left(\mathrm{~m}, 12 \mathrm{H}, \mathrm{CH}_{2}\right), 4.59\left(\mathrm{t}, 8 \mathrm{H}, J=13.6 \mathrm{~Hz}, \mathrm{NCH}_{2}\right), 7.63(\mathrm{t}, 2 \mathrm{H}, J=$ $6.6 \mathrm{~Hz}, \mathrm{Ar}-\mathrm{H}), 8.27$ (d, $4 \mathrm{H}, J=6.6 \mathrm{~Hz}, \mathrm{Ar}-\mathrm{H}), 8.82$ (s, $2 \mathrm{H}, \mathrm{Ar}-\mathrm{H})$.

Di-metabenzenotetra(5', 2'-tetrazolo)[5'-(2)-2'-(8)]-cyclophane (1-N, 2-N', 2-N", 2-N"') (6b).

White solid. Analysis: Found: C, 59.45; H, 6.20; N, 34.35. Calc. For $\mathrm{C}_{32} \mathrm{H}_{40} \mathrm{~N}_{16}$ : C, 59.24; H, 6.21; N, 34.54; Yield: 24 mg, $9.0 \%, 0.04$ mmol; $R_{\mathrm{f}} 0.41$ (50 : 50 hexane : ethyl acetate); M.p. 136-142 ${ }^{\circ} \mathrm{C}$; $v_{\max }(\mathrm{KBr}) 3436,2938,2860,1623,1520,1433,1390,1358,1199,1087,1045,911,810,787$, 744, $691 \mathrm{~cm}^{-1} ; \delta_{\mathrm{H}}: 1.23\left(\mathrm{~m}, 22 \mathrm{H}, \mathrm{CH}_{2}\right), 1.72\left(\mathrm{~m}, 2 \mathrm{H}, \mathrm{CH}_{2}\right), 4.48\left(\mathrm{t}, 2 \mathrm{H}, J=14.6 \mathrm{~Hz}, \mathrm{~N}^{1} \mathrm{CH}_{2}\right)$, $4.64\left(\mathrm{t}, 6 \mathrm{H}, J=13.5 \mathrm{~Hz}, \mathrm{~N}^{1} \mathrm{CH}_{2}\right), 7.63$ (t, $\left.2 \mathrm{H}, J=6.6 \mathrm{~Hz}, \mathrm{Ar}-\mathrm{H}\right), 7.81(\mathrm{~d}, 2 \mathrm{H}, J=6.6 \mathrm{~Hz}, \mathrm{Ar}-\mathrm{H})$, $8.27(\mathrm{~d}, 2 \mathrm{H}, J=6.6 \mathrm{~Hz}, \mathrm{Ar}-\mathrm{H}), 8.83(\mathrm{~s}, 2 \mathrm{H}, \mathrm{Ar}-\mathrm{H}) ; \delta_{\mathrm{C}}: 25.9,26.0,26.1,26.1,28.4,28.4,28.5$, 28.5, 28.6, 28.8, 29.1, 29.2, 47.3 (tetrazole N1- $\mathrm{CH}_{2}$ ), 52.8 (tetrazole N2- $\mathrm{CH}_{2}$ ), 52.8 (tetrazole N2$\mathrm{CH}_{2}$ ), 53.1 (tetrazole N2- $\mathrm{CH}_{2}$ ), 123.1, 124.8, 125.3, 127.4, 127.7, 129.5, 129.8, 129.9, 130.1, 130.5, 130.9, 153.9 (1,5-tetrazole), 162.9 (2,5-tetrazole), 164.1 (2,5-tetrazole), 164.3 (2,5-tetrazole); HRMS (EI) Calc. 649.3700, Found 649.3688.

Di-parabenzenotetra(5', 2'-tetrazolo)[5'-(2)-2'-(4)]-cyclophane (2-N, 2-N', 2-N", 2-N"') (7a).

White solid. Analysis: Found: C, 53.45; H, 4.41; N, 41.83. Calc. For $\mathrm{C}_{24} \mathrm{H}_{24} \mathrm{~N}_{16}$ : C, 53.72; H, 4.51; N, 41.77; Yield: $82 \mathrm{mg}, 30.6 \%, 0.15 \mathrm{mmol} ; \mathrm{R}_{\mathrm{f}} 0.52$ (50: 50 hexane : ethyl acetate); M.p. > $300{ }^{\circ} \mathrm{C}$; $v_{\max }(\mathrm{KBr}) 3150,3090,2950,2830,1725,1500,1478,1465,1440,1390,1359,1285,1178,1037$, 787, 770, 733, $665 \mathrm{~cm}^{-1}$; $\delta_{\mathrm{H}}: 2.09\left(\mathrm{~m}, 8 \mathrm{H}, \mathrm{CH}_{2}\right), 4.69\left(\mathrm{t}, 8 \mathrm{H}, J=13.5 \mathrm{~Hz}, \mathrm{NCH}_{2}\right), 7.97(\mathrm{~s}, 8 \mathrm{H}, \mathrm{Ar}-$ $\mathrm{H}) ; \delta_{\mathrm{C}}: 29.7,52.0$ (tetrazole N2-CH ), 127.1, 129.6, 164.6 (2,5-tetrazole); HRMS (EI) Calc. 537.2448, Found 537.2463.

Di-parabenzenotetra(5', 2'-tetrazolo)[5'-(2)-2'-(6)]-cyclophane (2-N, 2-N', 2-N", 2-N'") (8a).

White solid. Analysis: Found: C, 56.45; H, 5.20; N, 37.95. Calc. For $\mathrm{C}_{28} \mathrm{H}_{32} \mathrm{~N}_{16}$ : C, 56.74; H, 5.44; N, 37.81; Yield: 84 mg, $31.3 \%, 0.14$ mmol; $\mathrm{R}_{\mathrm{f}} 0.50$ (50 : 50 hexane : ethyl acetate); M.p. 240-244 ${ }^{\circ} \mathrm{C}$; $v_{\max }(\mathrm{KBr}) 3150,3090,2924,2860,1623,1450,1379,1281,1205,1125,1075,1048,860,746$ $\mathrm{cm}^{-1} ; \delta_{\mathrm{H}}: 1.33\left(\mathrm{~m}, 8 \mathrm{H}, \mathrm{CH}_{2}\right), 2.04\left(\mathrm{~m}, 8 \mathrm{H}, \mathrm{CH}_{2}\right), 4.66\left(\mathrm{t}, 8 \mathrm{H}, J=13.8 \mathrm{~Hz}, \mathrm{NCH}_{2}\right), 8.17(\mathrm{~s}, 8 \mathrm{H}$, 
Ar-H); $\delta_{\mathrm{C}}: 25.3,29.7,52.8$ (tetrazole N2-CH ), 127.3, 129.0, 164.6 (2,5-tetrazole); HRMS (EI) 593.3074, Found 593.3088.

Di-parabenzenotetra(5', 2'-tetrazolo)[5'-(2)-2'-(6)]-cyclophane (1-N, 2-N', 2-N", 2-N"') (8b).

Off-white solid. Analysis: Found: C, C, 56.40; H, 5.68; N, 37.45. Calc. For $\mathrm{C}_{28} \mathrm{H}_{32} \mathrm{~N}_{16}$ : C, 56.74; H, 5.44; N, 37.81; Yield: $27 \mathrm{mg}, 10.2 \%, 0.05 \mathrm{mmol}$; $\mathrm{R}_{\mathrm{f}} 0.39$ (50 : 50 hexane : ethyl acetate); M.p. 160-164 ${ }^{\circ} \mathrm{C}$; $v_{\max }(\mathrm{KBr}) 3150,3090,2926,2856,1629,1556,1451,1359,1275,1196,1046,1003$, 854, 746, 729, $670 \mathrm{~cm}^{-1}$; $\delta_{\mathrm{H}}: 1.30\left(\mathrm{~m}, 8 \mathrm{H}, \mathrm{CH}_{2}\right), 1.75\left(\mathrm{~m}, 2 \mathrm{H}, \mathrm{CH}_{2}\right), 1.86\left(\mathrm{~m}, 4 \mathrm{H}, \mathrm{CH}_{2}\right), 1.99(\mathrm{~m}$, $\left.2 \mathrm{H}, \mathrm{CH}_{2}\right), 4.03\left(\mathrm{t}, 2 \mathrm{H}, J=14.5 \mathrm{~Hz}, \mathrm{~N}^{1} \mathrm{CH}_{2}\right), 4.61\left(\mathrm{t}, 6 \mathrm{H}, J=13.6 \mathrm{~Hz}, \mathrm{~N}^{2} \mathrm{CH}_{2}\right), 7.61(\mathrm{~m}, 4 \mathrm{H}, \mathrm{Ar}-$ H), $7.85(\mathrm{~d}, 2 \mathrm{H}, J=6.6 \mathrm{~Hz}, \mathrm{Ar}-\mathrm{H}) ; 8.17(\mathrm{~s}, 8 \mathrm{H}, \mathrm{Ar}-\mathrm{H}), 8.38(\mathrm{~d}, 2 \mathrm{H}, J=6.6 \mathrm{~Hz}, \mathrm{Ar}-\mathrm{H}) ; \delta_{\mathrm{C}}: 25.1$, 25.3, 25.4, 25.5, 28.2, 28.6, 28.7, 28.8, 47.1 (tetrazole $\mathrm{N} 1-\mathrm{CH}_{2}$ ), 52.5 (tetrazole $\mathrm{N} 2-\mathrm{CH}_{2}$ ), 52.7 (tetrazole N2- $\mathrm{CH}_{2}$ ), 53.4 (tetrazole N2- $\mathrm{CH}_{2}$ ), 129.1, 125.5, 122.8, 127.2, 127.5, 127.7, 129.5, 153.8 (1,5-tetrazole), 162.8 (2,5-tetrazole), 164.1 (2,5-tetrazole), 164.1 (2,5-tetrazole); HRMS (EI) Calc. 593.3074, Found 593.3057.

Di-parabenzenotetra(5', 2'-tetrazolo)[5'-(2)-2'-(8)]-cyclophane (2-N, 2-N', 2-N", 2-N"') (9a).

White solid. Analysis: Found: C, 59.06; H, 6.18; N, 34.54. Calc. For $\mathrm{C}_{32} \mathrm{H}_{40} \mathrm{~N}_{16}$ : C, 59.24; H, 6.21; N, 34.54; Yield: $50 \mathrm{mg}, 18.5 \%, 0.08$ mmol; $\mathrm{R}_{\mathrm{f}} 0.53$ (50 : 50 hexane : ethyl acetate); M.p. 284-286 ${ }^{\circ} \mathrm{C} ; v_{\max }(\mathrm{KBr}) 3150,3090,2925,2855,1624,1520,1455,1431,1390,1366,1210,1085,1045$, 909, 786, 745, 690, $670 \mathrm{~cm}^{-1} ; \delta_{\mathrm{H}}: 1.32\left(\mathrm{~m}, 8 \mathrm{H}, \mathrm{CH}_{2}\right), 1.36\left(\mathrm{~m}, 8 \mathrm{H}, \mathrm{CH}_{2}\right), 2.04\left(\mathrm{~m}, 8 \mathrm{H}, \mathrm{CH}_{2}\right), 4.62$ (t, $\left.8 \mathrm{H}, J=13.3 \mathrm{~Hz}, \mathrm{NCH}_{2}\right), 8.25(\mathrm{~s}, 8 \mathrm{H}, \mathrm{Ar}-\mathrm{H}) ; \delta_{\mathrm{C}}: 25.9,28.5,29.2,53.2$ (tetrazole N2- $\mathrm{CH}_{2}$ ), 127.3, 129.1, 164.6 (2,5-tetrazole); HRMS (EI) Calc. 649.3700, Found 649.3720.

\section{X-Ray Crystallography}

Crystals of 1a, 5a and 7a suitable for X-ray analysis were obtained by recrystallisation from chloroform solution. Data were collected at 180(2) K on a Bruker Nonius X8 APEX II diffractometer, ${ }^{12}$ and a multi-scan correction was applied. ${ }^{13}$ The structures were refined against $F^{2}$ using all data. ${ }^{14}$ Hydrogen atoms were placed at calculated positions and refined using a riding model.

Compound 1a. Crystal data: $\mathrm{C}_{24} \mathrm{H}_{24} \mathrm{~N}_{16}, M=536.59$, triclinic, $a=8.5805(3), b=8.7679(4), c=$ 9.4091(4) ̊, $\alpha=81.976(2), \beta=70.235(2), \gamma=66.642(2)^{\circ}, U=611.56(5) \AA^{3}$, space group $P-1, Z=$ $1, \mu(\mathrm{Mo}-\mathrm{K} \alpha)=0.099 \mathrm{~mm}^{-1}, \rho_{\text {calc }}=1.457 \mathrm{~g} \mathrm{~cm}^{-3} .22917$ data $\left(2300\right.$ unique, $\left.R_{\text {int }}=0.0243\right)$ were 
measured in the range $4.07<\theta<25.74^{\circ} . R_{1}(I>2 \sigma(I))=0.0292$ and $w R_{2}$ (all data) $=0.0740$. Goodness of fit on $F^{2}=1.05$. CCDC No. 633941 .

Compound 5a. Crystal data: $\mathrm{C}_{28} \mathrm{H}_{32} \mathrm{~N}_{16}, M=592.70$, monoclinic, $a=6.8210(6), b=24.146(3), c=$ 8.7297(10) $\AA, \beta=96.924(4)^{\circ}, U=1427.3(3) \AA^{3}$, space group $P 2{ }_{1} / n, Z=2, \mu($ Mo-K $\alpha)=0.092 \mathrm{~mm}^{-}$ ${ }^{1}, \rho_{\text {calc }}=1.379 \mathrm{~g} \mathrm{~cm}^{-3} .17057$ data $\left(2620\right.$ unique, $\left.R_{\text {int }}=0.0600\right)$ were measured in the range $3.59<\theta$ $<25.43^{\circ} . R_{1}(I>2 \sigma(I))=0.0441$ and $w R_{2}($ all data $)=0.1194$. Goodness of fit on $F^{2}=1.01$. CCDC No. 633942.

Compound 7a. Crystal data: $\mathrm{C}_{24} \mathrm{H}_{24} \mathrm{~N}_{16}, M=536.59$, triclinic, $a=6.7596(12), b=7.1970(12), c=$ 12.9550(19) $\AA, \alpha=91.008(7), \beta=100.326(6), \gamma=100.409(6)^{\circ}, U=609.02(17) \AA^{3}$, space group $P$ $1, Z=1, \mu($ Mo-K $\alpha)=0.099 \mathrm{~mm}^{-1}, \rho_{\text {calc }}=1.463 \mathrm{~g} \mathrm{~cm}^{-3} .10192$ data (2101 unique, $\left.R_{\text {int }}=0.0602\right)$ were measured in the range $3.76<\theta<25.14^{\circ} . R_{1}(I>2 \sigma(I))=0.0716$ and $w R_{2}$ (all data) $=0.2158$. Goodness of fit on $F^{2}=1.11$. CCDC No. 633943.

\section{Supplementary material}

Crystallographic data for 1a, 5a and 7a have been deposited with the Cambridge Crystallographic Data Centre, CCDC Nos. 633941-633943. Copies of this information may be obtained free of charge from deposit@ccdc.cam.ac.uk or www:http://www.ccdc.cam.ac.uk

\section{Acknowledgements}

We thank the Postgraduate R\&D Skills programme (Technological Sector Research, Strand III, Project Code CRS01/TA02) for financial assistance. A. D. B. is grateful to the Danish Natural Sciences Research Council and the Carlsberg Foundation for provision of the X-ray equipment.

\section{References}

1. a) Butler, R. N. in Comprehensive Heterocyclic Chemistry; Katritzky, A. R.; Rees, C. W.; and Scriven, E. F. V. Eds.; Permagon: Oxford, U.K., 1996, Vol. 4; b) Herr, R. J. Bioorg. \& Med. Chem. 2002, 10, 3379-3393; c) Ostrovskii, V. A.; Pevzner, M. S.; Kofman, T. P.; Shcherbinin, M. B.; Tselinskii, I. V. Targets Heterocycl. Syst. 1999, 3, 467-526.

2. a) Sisido, K.; Nabika, K.; Isida, T.; Kozima, S. J. Organomet. Chem. 1971, 33, 337-346; b) Demko, Z. P.; Sharpless, K. B. J. Org. Chem. 2001, 66, 7945-7950. 
3. a) Stassen, A. F.; Grunert, M.; Mills, A. M.; Spek, A. L.; Haasnoot, J. G.; Reedijk, J.; Linert, W. Dalton Trans. 2003, 3628-3633; b) Wu, T.; Yi, B.-H.; Li, D. Inorg. Chem. 2005, 44, 41304132; c) Wu, T.; Zhou, R.; Li, D. Inorg. Chem. Commun. 2006, 9, 341-345; d) Yu, Z.; Wang, X.; Feng, Y.; Zhong, X. Inorg. Chem. Commun. 2004, 7, 492-494.

4. Fleming, A.; Kelleher, F.; Mahon, M. F.; McGinley, J.; Prajapati, V. Tetrahedron 2005, 61, 7002-7011.

5. a) Bond, A. D.; Fleming, A.; Kelleher, F.; McGinley, J.; Prajapati, V. Tetrahedron 2006, 62, 9577-9581; b) Fleming, A. F. M.; Kelleher, F.; Mahon, M. F.; McGinley, J.; Molloy, K. C.; Prajapati, V. Acta Cryst. 2004, E60, 2388-2389.

6. a) Butler, R. N.; Quinn, K. F.; Welke, B. J. Chem. Soc., Chem. Commun. 1992, 1481-1482; b) Butler, R. N.; Ní Bhrádaigh, E. P. J. Chem. Res.(S), 1994, 148-149; c) Butler, R. N.; Fleming, A. F. M. J. Heterocycl. Chem. 1997, 34, 691-693.

7. Butler, R. N.; McGinley, J.; Mahon, M. F.; Molloy, K. C.; Ní Bhrádaigh, E. P. Acta Cryst. 2001, E57, o195-o197.

8. Bethel, P. A.; Hill, M. S.; Mahon, M. F.; Molloy, K. C. J. Chem. Soc., Perkin Trans. 1, 1999, 3507-3514.

9. Allen, F. H. Acta Cryst. 2002, B58, 380-388.

10. (a) Bhandari, S., Mahon, M. F., Molloy, K. C., Palmer, J. S., Sayers, S. F. J. Chem. Soc., Dalton Trans., 2000, 1053-1060; (b) Reid, W., Aboul-Fetouh, S. Tetrahedron, 1988, 44, 3399-3404; (c) Hill, M. S., Mahon, M. F., McGinley, J., Molloy, K. C. J. Chem. Soc., Dalton Trans., 1996, 835-845; (d) Jiang, C., Yu, Z., Jiao, C., Wang, S., Li, J., Wang, Z., Cui, Y. Eur. J. Inorg. Chem., 2004, 4669-4674; (e) Tao, J., Ma, Z.-J., Huang, R.-B., Zheng, L.-S. Inorg. Chem., 2004, 43, 6133-6135; (f) Diop, C. A. K., Mahon, M. F., Molloy, K. C., Ooi, L., Raithby, P. R., Venter, M. M., Teat, S. J. CrystEngComm., 2002, 4, 462-466; (g) Hill, M. S., Mahon, M. F., Molloy, K. C. J. Chem. Soc. Dalton Trans., 1996, 1857-1865.

11. Slavin, A. M. Z., Spencer, N., Stoddart, J. F., Williams, D. J. Chem. Commun., 1987, 10701072.

12. See, for example, (a) Lin, P., Clegg, W., Harrington, R. W., Henderson, R. A. Dalton Trans., 2005, 2388-2394; (b) Boyko, V., Rodik, R., Danylyuk, O., Tsymbal, L., Lampeka, Y., Suwinska, K., Lipkowski, J., Kalchenko, V. Tetrahedron, 2005, 61, 12282-12287; (c) Friedrich, M., Gálvez-Ruiz, J. C., Klapötke, T. M., Mayer, P., Weber, B., Weigand, J. J. Inorg. Chem., 2005, 44, 8044-8052; (d) Shvedenkov, Y., Bushuev, M., Romanenko, G., Lavrenova, L., Ikorskii, V., Gaponik, P., Larionov, S. Eur. J. Inorg. Chem., 2005, 1678-1682; (e) Mo, X.-J., Gao, E.-Q., He, Z., Li, W.-J., Yan, C.-H. Inorg. Chem. Commun., 2004, 7, 353-355.

13. Bruker Nonius. APEX2. Version 1.0-22. Bruker Nonius BV, Delft, The Netherlands, 2004. 
14. G. M. Sheldrick, SADABS. Version 2.10. Bruker AXS Inc., Madison, Wisconsin, USA, 2003.

15. G. M. Sheldrick, SHELXTL. Version 6.10. Bruker AXS Inc., Madison, Wisconsin, USA, 2000. 